Kovács, N. (2020). Szellemi örökség a globális térben: a hagyomány és az autentikus táncélmény

keresése a tangó nemzetközi világában. Tánc és Nevelés. Dance and Education, 1(1), 113-129.

DOI: https:// doi.org/10.46819/TN.1.1.113-129

\title{
SZELLEMI ÖRÖKSÉG A GLOBÁLIS TÉRBEN: A HAGYOMÁNY ÉS AZ AUTENTIKUS TÁNCÉLMÉNY KERESÉSE A TANGÓ NEMZETKÖZI VILÁGÁBAN
}

\author{
Kovács Nóra PhD, tudományos munkatárs, Magyar Tudományos Akadémia, \\ Társadalomtudományi Kutatóközpont
}

\begin{abstract}
Absztrakt
Az 'argentin és uruguay-i tangó' az emberiség kiemelkedő kulturális teljesítményeként 2009-ben bekerült az UNESCO védendő szellemi örökségeinek jegyzékébe. A tangót társadalmi jelenségként vizsgáló kutatók közül többen felhívták a figyelmet a tangó felterjesztésével és örökségesítésével kapcsolatos ellentmondásokra és hiányosságokra. A felterjesztés szövegére és az örökségesítési döntésre irányuló kritikák két fő problémakörre összpontosítottak és két eltérő nézőpontból fogalmazódtak meg. A tangó, mint örökség meghatározásából mindkét megközelítés hiányolta az alulról szerveződő, élő tangóközösségeket és az általuk képviselt értékeket. Ez a dolgozat a tangó örökségesítésére adott tudományos és közösségi reakciókat kívánja összekapcsolni a tangó nemzetközi, kiváltképpen európai világában megfigyelt fejlődési irányokkal, különösen az úgynevezett tangó maraton, illetve encuentro milonguero ${ }^{1}$ elnevezésú két-három napos nemzetközi táncesemények növekvő elterjedésével. A tangó összetett és sokszínú globális világában ezekhez a tánceseményekhez a táncosok számára az alapvetô és autentikus milonga-tapasztalat, valamint a közös tánctérben megélt táncokon keresztül megvalósuló bensőségesség és közösség élményei kapcsolódnak.
\end{abstract}

Kulcsszavak: szellemi kulturális örökség, argentin tangó, tangó maraton, ecuentro milonguero, autentikus táncélmény, táncantropológia

\section{BEVEZETÉS}

Ez a dolgozat a tangó világára, egy Dél-Amerikában keletkezett és globálisan létezô városi társasági tánc rétegkultúrájára fókuszál. Az 'argentin és uruguay-i tangó’ 2009-ben bekerült az UNESCO Szellemi Kulturális Örökség jegyzékébe, mint az emberiség egyik kiemelkedő és óvandó kulturális teljesítménye. Az UNESCO által elfogadott dokumentumban a tangónak egy szúk és hiányos meghatározása szerepel, amely nem foglalta magában a tangó világának az elmúlt harminc évben Argentínán és Uruguay-on kívül bekövetkezett fejleményeit. Írásom a tangó örökségesítésére adott tudományos és közösségi reakciókat kívánja összekapcsolni a tangó nemzetközi, kiváltképpen európai világában megfigyelt fejlődési irányokkal, különösen az úgynevezett tangó maraton, illetve encuentro milonguero

\footnotetext{
${ }^{1}$ Milonguero stílusú, azaz közeli tánctartás gyakorlatát érvényesító tangó-találkozók.
} 


\section{Kovács Nóra}

elnevezésú két-három napos nemzetközi táncesemények növekvő elterjedtségével. Szorosan kapcsolódó kérdésként vethetô fel, hogy mi tekinthetô autentikus tánctapasztalatnak az argentin tangó élő, folyamatosan fejlődő, globális nemzetközi világában.

A 2000-es évek végén, és a 2010-es évtized elején az argentin tangó magyarországi szubkultúrájának több szereplője számolt be egy újfajta táncalkalom térnyeréséről Európában és Magyarországon is. Ezek a társasági táncosok nemcsak a helyi klubokat és tangórendezvényeket látogatták, hanem elkezdtek rendszeresen nemzetközi tangótalálkozókra járni Európa országaiban azzal a céllal, hogy ott egy egész hétvégén keresztül, akár csak minimális megszakításokkal táncolhassanak a legkülönfélébb országokból érkezô tangósokkal. 2013-ban egy hosszabb beszélgetést folytattam a tangó világának változásairól a budapesti Hédivel, egy negyvenes évei elején járó, egyetemet végzett és a szakmájában sikeresen dolgozó tapasztalt társasági tangótáncosnővel². Hédi ebben az időszakban intenzív tangóéletet élt. Amellett, hogy számos baráti kapcsolatot ápolt a tangós világ résztvevőivel, hetente több este lejárt a helyi klubokba, rendszeres magánórákon csiszolta tovább haladó tánctudását, és gyakran utazott külföldi táncalkalmakra is. Élénk szavakkal írta le közelmúltbeli és tervezett külföldi tangós útjait. Beszélgetésünk során rákérdeztem, miként szokta megoldani a nemzetközi fesztiválok gyakran felmerülő problémáit, azaz, hogy a fesztiválok keretén belül megtartott táncórákon csak előre egyeztetett táncpartnerrel lehet részt venni, illetve, hogy a táncalkalmakon jellemzően több követô szerepben táncoló, jellemzően női táncos van jelen, mint vezetô, és emiatt biztosan lesznek olyan résztvevők, akik kimaradnak a táncból. Hédi így fogalmazta meg az új táncalkalom-típus előnyeit:

Már nem úgy van, mint pár éve, már nem fesztiválra járunk. Mostanában tangó maratonokra megyek, vagy még jobb az encuentro milonguero. Kevesebben vesznek részt rajtuk, mint a fesztiválokon, bensőségesebbek, a nemek aránya kiegyenlített, és a táncban elvárás a közeli tánctartás. Nem kell órákon részt venni, nem kell időról-időre bemutatókat nézni a tánc helyett; az egész hétvége csak zene és tánc. Legutóbb Észak-Olaszországban voltam... a helyi táncosok baráti köre hihetetlen módon látott vendégül bennünket. Fantasztikus volt. Házi süteményeket és salátákat hoztak a milongákra, többünket a saját otthonaikban szállásoltak el; barátságos és meleg volt a légkör.

A Hédivel folytatott beszélgetés tehát a nemzetközi, főleg az európai tangóvilág egy olyan trendjére hívta fel a figyelmet, amelyben egy látszólag új nemzetközi táncesemény-típus kezdett meghatározóvá válni. A tangóval kapcsolatos társadalmi gyakorlatok és a címben említett autentikusság a tangó kultúrájának számos megnyilvánulási területéhez, például a táncmozdulatokhoz vagy a zenéhez is kapcsolható. Ebben az írásban e kifejezés azokkal a táncalkalmakkal összefüggésében jelenik meg, ahol a tangó, mint társadalmi gyakorlat és közösségi cselekvés valósul meg.

${ }^{2}$ A szövegben szereplő adatközlők neveit megváltoztattam. 


\section{A TANGÓ ÚJJÁÉLEDÉSE BUENOS AIRESBEN A KATONAI DIKTATÚRA UTÁN}

Terjedelmi okokból itt csak röviden utalhatunk a tangó újjáéledésnek történelmi folyamatára. Ennek során az argentin katonai diktatúrát követően az 1980-as évek közepétől a kissé poros és megkopott, a városi alsó néposztályokhoz köthető, „proli” tangót újraértékelte és szélesebb körben is magáénak tekintette az argentin társadalom (lásd Morel, 2012). Az ezredfordulóra a tangó megújulása javában zajlott Argentínában, bár Buenos Airesben ezt az időszakot még közel sem jellemezték a hatalmas nemzetközi tangófesztiválok, a tangós tömegrendezvények és tangóbajnokságok. $\mathrm{Az}$ argentin fôváros tangós világában évről évre több klub múködött, köztük számos olyan, amelynek közönsége meghatározóan fiatalokból állt. Rohamosan nőtt a tangóiskolák és a tangóval professzionálisan foglalkozó táncosok, tanárok, zenészek és DJ-k száma is. Emellett két rendszeres tangómagazin is megjelent, programajánlókkal, interjúkkal és tangótörténeti írásokkal. Ezekhez képest az ezredforduló óta eltelt két évtized során még nagyobb horderejú változások következtek be a tangó a La Plata vidéki és nemzetközi világában egyaránt. Ezek egy része technikai vívmányokhoz köthető, az internet széleskörú elterjedéséhez, a videó megosztó platformokhoz, a közösségi média térhódításához, a jó minőségú mozgóképet rögzítő eszközök elérhetőségéhez, amelyek egyébként más fizikai mozgáshoz kapcsolódó szubkultúrákban is nagy változásokat hoztak.

\section{FELHASZNÁLT ADATOK, MEGKÖZELÍTÉS}

Jelen tanulmány az argentin tangó magyarországi, európai és argentínai világában való részvétel során összegyuujtött lágy adatokon és megfigyeléseken alapul; ezeket egészítették ki a személyes adattáramban összegyúlt jegyzetek, fényképek, dokumentumok, hanglemezek és a tangó kultúrájához kapcsolódó tárgyak.

Egy hosszabb Buenos Aires-i tartózkodás időszakában, 1999-ben kezdtem el tangó témájú terepnaplót írni, amelyet kisebb-nagyobb megszakításokkal húsz éve vezetek. Az első öt év során a bejegyzések többsége az argentínai órák során tanult mozdulatokról és technikákról szólt; ezek mellett a táncparkett szabályairól, illetve azon délutáni és esti a milongákon megfigyelt viselkedési mintázatokról és etikettról, amelyeket rendszeresen látogattam az argentin fővárosban. Több bejegyzés szólt arról, miként vélekedtek a tangóról ebben az időszakban azok az argentin ismerőseim, akik soha életükben nem jártak tangót. A dolgozat elkészítése során a tangó nemzetközi szakirodalma mellett felhasználtam olaszországi, ausztriai, szlovéniai és magyarországi tangó maratonok és encuentro milonguero-k alapján készült feljegyzéseimet.

Jelen írás nem a tánctudomány perspektívájából, és alapvetően nem előadómúvészeti ágként vizsgálja a tangót, hanem táncantropológiai megközelítésben elsősorban a tangóval kapcsolatos egyéni tapasztalatokra és közösségi gyakorlatokra és ezek társadalmi kontextusára irányul. 


\section{AZ ARGENTIN TANGÓ A KUTATÁS CÉLKERESZTJÉBEN: RÖVID ÁTTEKINTÉS}

A tangó eredetileg a La Plata folyó térségének alsó társadalmi rétegeihez köthető kulturális hagyományrendszer volt, amely többféle múfajt foglalt magába: zenét, dalszöveget, egy komplex mozgásrendszert, a spanyol nevükön milongának nevezett táncalkalmakat, valamint egy magatartáskódexet, emellett egy tárgyi világot is. Bár a tangó tényleges központja Buenos Aires volt és valószínúsíthetően lesz is, dinamikusan alakuló globális jelenséggé vált. Szerte a világon több tízezer városlakó életének meghatározó szabadidős tevékenysége lett. Több kiváló antropológiai munka etnográfiai leírása számol be finom részletességgel arról, hogy milyen mélységben hatja át és változtatja meg a világ különböző városaiban élő, a tangóval még ismerkedő vagy azt már régóta múvelő egyének életét és önazonosságát a tangó tanulása: a tangó sétatechnikájának, a lépéskombinációknak, az improvizáció belsô logikájának és esztétikájának elsajátítása (lásd pl. Davis, 2015), hogy csupán néhány példát említsünk.

Ezekrôl és más, a tangóval kapcsolatos jelenségekről Argentínában és szerte a világon nagyon sokat megtudhatunk a tangó elmúlt évtizedek alatt keletkezett kiterjedt szakirodalmából. A tangó kutatástörténetének felvázolása ebben a dolgozatban nem cél, de fontos hangsúlyozni, milyen sokféle megközelítésből, hányféle módszertannal igyekezték kutatók megragadni különféle aspektusait, jóval azelőtt, hogy 2009-ben bekerült volna az emberiség óvandó szellemi örökségének jegyzékébe.

Argentínában már jóval a tangó 1990-es években fellendülő újjáéledési folyamata, valamint népszerúségének helyi és nemzetközi erősödése előtt felébredt az érdeklődés az eltűnő félben lévő tangóvilág részleteinek megörökítésére. Köteteket publikáltak a tangózenekarok (orquesta típica) történetérôl (Sierra, 1985), a tangó dalszövegeiből (Gobello, 1997), és arról is, hogy függ össze a tangó kultúrája az argentin férfiszerepekkel (Archetti, 1999, 2003). Közreadták a zeneszerzők, zenekarok, klubok és zeneszámok jelentős inventáriumát (Ferrer és del Priore, 2000), egy történelmi tangós személyiségek életrajzait tartalmazó kötetet (Anzzi, 1991), és tangótörténeti múveket is (pl. Larbaña és Sebastian, 2000). A tangó nemzetközi népszerûségéhez nagyban hozzájáruló táncospár, Gloria és Rodolfo Dinzel megalkottak egy olyan rendszert, amely megkísérelte modellezni a mozgásvilágban rejlő improvizációs lehetőségeket (Dinzel és Dinzel, 1997).

Minthogy a tangózás jellemzően „magába szippantja” és nagymértékben leköti múvelői figyelmét, számos eredetileg más területen kutató társasági tangótáncos tette saját személyes tapasztalatát újabb kutatásainak kiindulópontjává. Közéjük tartozik Marta E. Savigliano, akinek Tango and the political economy of passion (1995) címú meghatározó munkája a tangó társadalomtörténetét Argentína posztkoloniális kontextusában és a nemzetközi hatalmakhoz fưződő kapcsolatán keresztül rajzolta meg. A tangó, mint tánc elsajátításának személyes folyamatát és a katonai diktatúrát elszenvedő Argentína helyzetét innovatív módon ragadta meg és kapcsolta össze a táncos és antropológus professzor Julie Taylor Paper Tangos (1998) címú könyvében. Az egészségtudományok területérôl többen vizsgálták, hogy a tánc és ezen belül megkülönbözetett módon az improvizációra épülő tangó hogyan befolyásolja múvelői személyes jólétét valamint öregedésük folyamatát (Skinner, 2014), miként segíthet a Parkinson kór (Lötzke et al., 2015) vagy a depresszió (Pinniger et. al., 2012) elleni 
küzdelemben. A legtöbb személyes tánctapasztalatból kiinduló vizsgálódás tárgyalja azt is, hogy e tevékenység miként alakítja át a tangózók személyes identitását (pl. Davis, 2015). Születtek írások a tangóról, amelyek egyes aspektusait kulturális viselkedési kódként igyekeztek megközelíteni (Kovács, 2016). Számos kutató elemezte a tangó hagyományrendszerének a társadalmi nemekkel kapcsolatos vonatkozásait, valamint tangóklubokban meglévő hatalmi egyenlőtlenségeket nók és férfiak között (pl. Törnquist, 2013; Savigliano, 1995). Az amerikai feminista szociológusnő, Kathy Davis hosszú okfejtésen keresztül kísérli megérteni a tangóban rejlő ún. gender-paradoxont, azt, hogy egy feminista szociológus hogy rajonghat szenvedélyesen olyasvalamiért, amit alapjaiban jellemez a nemek közötti egyenlőtlenség (Davis, 2015; Kovács, 2015). Ugyancsak széles körben kutatták a tangót a migráció, a globalizáció és a turizmus vonatkozásában is (Viladrich, 2013; Törnquist, 2013; Stepputat, 2017). Az autenticiás problémakörét ugyancsak tárgyalták a tangó vonatkozásában (Skinner, 2019).

\section{A TANGÓ A SZELLEMI KULTURÁLIS ÖRÖKSÉG JEGYZÉKÉBEN}

Argentína és Uruguay együtt terjesztették fel a Tangót a Szellemi Kulturális Örökség jegyzékébe, ahova 2009-ben be is került. Az erról szóló egyoldalas dokumentum az UNESCO weboldalán a tangónak egy rövid, ám viszonylag tág és pontatlan meghatározását adja. Utal arra, hogy eredetét tekintve a bevándorlók alsó társadalmi osztályaihoz köthetô, és jelzi, hogy többféle múfaj (zene, tánc, líra) kapcsolódik hozzá. Mi több, megállapítja, hogy „a tangót Buenos Aires és Montevideo hagyományos tánctermeiben múvelik, terjesztve a földgolyón közösségének szellemét még úgy is, hogy új környezetekhez és változó idôkhöz adaptálódik. Ez a közösség ma zenészekből, professzionális és amatőr táncosokból, koreográfusokból, zeneszerzőkből, dalszövegírókból, e múvészet oktatóiból és a tangó kultúráját megtestesító élő nemzeti kincsekből áll" (UNESCO, 2009c).

Bár az identitás kifejezés három helyen is előfordul a dokumentumban, minden esetben a La Plata folyó vidékén élők kulturális identitására utal. Fentebb esett szó arról, hogy a tangó kultúrájával való azonosulásnak és a fizikai mozgásrendszer népszerúségégének a foka sokkal alacsonyabb volt Argentínában a 20. század végén, mint napjainkban, kivált az argentin középosztály körében. A tangóhanyatló népszerúségét az 1970-es és az 1980-as években jelentősen rombolták az argentin katonai kormányzat intézkedései, amelyek bezáratták a hagyományos tangó klubokat, mint a gyülekezés lehetséges helyszíneit (Savigliano, 1995; Taylor, 1998).

Az érdeklődés és a tangó mozgásrendszerével történő argentínai azonosulás érzékelhető hiánya egybevág a Buenos Airesben az 1990-es évek végén és a 2000-es évek elején szerzett tapasztalataimmal. Középosztálybeli barátaim és ismerőseim némi rosszallással vegyes értetlenséggel fogadták a tangó órák és klubok látogatása iránti lelkesedésemet. Az idősebbek (50-70 éves korig) többsége számára a milongák társadalmilag vállalhatatlan, kulturálatlan, „proli” intézmények számítottak, bár a tangó zene hallgatását és a táncórák látogatást elfogadhatóbbnak vélték. A fiatal generáció képviselői úgy gondolták, a tangó kissé poros, hiszen eljárt már felette az idő. Szintén személyes, de idevágó tapasztalat, hogy argentin ismerőseim közép- és felső-középosztálybeli közegében egészen kivételesen találkoztam csak olyan személlyel, aki részt vett akár csak egy táncórán is. 


\section{Kovács Nóra}

Az UNESCO szellemi kulturális örökségnek szentelt honlapja hatásos képekben jeleníti meg a tangót - alapvetően, mint színpadi tevékenységet (UNESCO, 2009a). Gyönyörködhetünk egy szóló táncospárban; fiatal professzionális tangótáncosok színpadi koreográfiájának egy pillanatában; tangózenekarok különbözó generációinak ugyancsak színpadi előadásain készült felvételeiben; valamint a nagy kortárs tangóénekesnőről, a tangó megújulásának egyik kulcsfigurájaként ünnepelt Susana Rinaldiról drámai megvilágításban készült fotóban. Ezek az ábrázolások egy kulturális hagyományrendszer egyik nagyon fontos és ténylegesen lenyưgöző aspektusát jelenítik meg, a színpadra vitt tangó show-t, amelyre Argentínában az angol "tango for export" kifejezéssel is szoktak utalni. Azonban hiányzik az ábrázolások közül a tangó azon alapvető és meghatározó oldala, amely évtizedek óta töretlen népszerûségnek örvendő városi táncos rétegkultúrává teszi szerte a világon.

Több évtizedes tánctapasztalattal rendelkező európai közösségek kicsit talán megütközve szembesülhettek ezzel a tangó-meghatározással. Ezek a nem is anynyira új keletú táncos kolóniák nagymértékben hozzájárultak és járulnak a tangó világához személyes önazonosságukkal, közösségi múködésükkel és azok értékeivel, a táncról és a zenéról felhalmozott tudásukkal, és sok egyébbel. Például az ezredforduló időszakában a múfaj iránt elkötelezett európai tangueró-k Magyarországról is rendszeresen Argentínából rendeltek speciális tangócipőt. Az utóbbi két évtized során azonban Európában olyan magas színvonalú manufaktúrák jöttek létre, amelyek múremekei több táncos véleménye szerint alkalmasságban, szépségben és kényelemben felülmúlják az argentin gyártókat, és nagyon népszerủek Európában.

\subsection{A tangó, mint szellemi kulturális örökség definíciójának problémái}

A tangó jegyzékbe vételével kapcsolatos hiányosságokra és ellentmondásokra több a tangóval, mint társadalmi jelenséggel foglalkozó kutató is felhívta a figyelmet. A felterjesztett dokumentumra és a jegyzékbe vételi döntés folyamatára irányuló kritikák két fő problémakörre összpontosítottak és két markánsan eltérő nézôpontból fogalmazódtak meg. E nézőpontok egyikét, amely megítélésem szerint a globális tangó világának a hangja, az osztrák etnomuzikológusnő és tangókutató Kendra Stepputat (2015), valamint a brit táncantropológus Jonathan Skinner (2019) fogalmazta meg. A másik kritikai pozíciót a nemzeti (argentin) tangó világának nézőpontjából Hernán Morel argentin antropológus artikulálta (2009, 2013, és 2017), amikor kutatásaival magyarázatot keresett a Buenos Airesben a tangó 2009-es örökségesítését követően fellángolt belső konfliktusokra. Stepputat és Morel mindketten hiányolták a tangó, mint szellemi kulturális örökség meghatározásából a tangó alulról szerveződô élő közösségeit és az általuk képviselt értékeket. Az írásaikban kiemelt problématerületre irányítja a figyelmet a nemzetközi, kivált az európai tangós világ növekvő érdeklődése a helyi közösségi értékeket, a bensősséget, valamint a Buenos Aires-i milongák hagyományos viselkedési kódját megtestesítő új, regionális vonzáskörú táncalkalom iránt. 


\section{Kovács Nóra}

\subsubsection{A nemzetközi tangós világ autentikusságának megkérdójelezése}

Az örökségesítés folyamat hiányosságaival kapcsolatban megfogalmazott szenvedélyes kritikájában Kendra Stepputat (2015) tesz néhány fontos megállapítást, amelyek összefoglalása alább következik.

A tangó kifejezés utalhat a La Plata vidékének kulturális hagyományrendszerére, de vonatkozhat egy teljesen eltérő mozdulatokból felépülő, a sztenderd táncok közé tartozó táncstílusra is, félreértésekre adva ezzel lehetőséget. A nemzetközileg általánosan használt argentin jelző Uruguay iránti tiszteletből nem szerepelt a felterjesztő dokumentumban. Bár a tangó jegyzékbe vétele a szokásos eljárást követte, a felterjesztő dokumentum tartalma és hangsúlyai az adott időpillanatban nagymértékben eltértek a tangó tényleges manifesztációitól. Stepputat kiemeli, hogy a tangó performatív múvészeti kultúrája egymáshoz kapcsolódó zenéból, táncból és költészetből áll, amelyet egyaránt múvelnek profik és amatőrök. Hangsúlyozza továbbá, hogy bár a tangó megkérdőjelezhetetlenül a La Plata vidékén alakult ki, többnyire magasan képzett városi középosztálybeli valamint felső-középosztálybeli egyének táncolják Európában, Észak- és Dél-Amerikában, Ázsiában és Ausztráliában. Az egyes helyi tangós közösségek általában nem túlzottan népesek, de egymással intenzív regionális és nemzetközi kapcsolatokat ápolnak a közösségi médián illetve látogatásokon keresztül. Kötődnek a Buenos Aires-i tangó világához is tangós „zarándoklatokon”, a közösségi médián és a világban utazó és oktató argentin tanárokon keresztül. Ezek a kapcsolatok évtizedek óta léteznek és egyre szorosabbá válnak. Stepputat joggal teszi fel a kérdést, hogy vajon a La Plata vidékének táncos gyakorlatai miért értékesebbek, mint a nemzetköziek, amelyek teljességgel kimaradtak a szellemi kulturális örökséggé nyilvánított tangó meghatározásából. Stepputat rámutat arra is, hogy az UNESCO az előterjesztés mérlegelésére hivatott kormányközi bizottsága részleges, és mint láthattuk, torzított információra alapozta az ítéletét. Nem konzultáltak nemzetközi tangószakértőkkel, nem tartottak terepszemlét, ami kétségeket ébreszthetett volna a felterjesztés tartalmi helytállóságát illetően.

Stepputat gondolatmenetét követve fontos itt egy további megállapítást tenni a felterjesztő dokumentum (UNESCO, 2009b:10-12) tangóra vonatkozó szakirodalmi hivatkozásaival kapcsolatban, amelyről Stepputat nem szól, mégis jó jellemzi a felterjesztő dokumentum szemléletét. Fentebb esett szó arról, hogy a tangóra jelentős tudományos figyelem irányult már évtizedekkel örökségesítési folyamatának kezdete előtt. A felterjesztő dokumentum azonban nem utalt a tangóról angol nyelven született munkákra, nem kerültek említésre Marta Savigliano, Julie Taylor és Eduardo Archetti korszakalkotó elemzései sem (lásd Hivatkozások). A tangó történetéről, a zenérôl és a dalszövegekről, a tangó világának rétegnyelvéről (lunfardo) szóló általánosabb áttekintések uralták a hivatkozott múvek jegyzékét.

Végezetül Stepputat azt állítja, hogy a tangó felterjesztését és örökségesítési folyamatát gazdasági és politikai célok vezérelték, amelyek nagyobb bevételt céloztak meg a tangó miatt megnövekvő kulturális iparból, és amelyek alapjaiban kérdőjelezik meg a tangónak az emberiség szellemi kulturális örökségévé nyilvánítását annak jelenlegi formájában. A felterjesztéshez vezető szándék a tangó szigorúan lokális kulturális hagyományként értelmezett újbóli birtokbavételét célozta 


\section{Kovács Nóra}

- az UNESCO segítségének felhasználásával. Ennek megvalósításához a tangónak egy részleges, eltorzított képét rajzolta meg, amely nyilvánvalóan kedvezett a helyi célok megvalósításának.

Az autentikusság és a szellemi kulturális örökség kérdéseit ugyancsak a globális tangó világának vonatkozásában tárgyalta Jonathan Skinner (2019). Az egyén tánctudásának minősége, a tánc oktatására való képessége és tangós autentikussága közti összetett és ellentmondásos kapcsolatot vizsgálta meg. Skinner olyan tanítási szituációkat elemzett Angliában, amelyek során az argentin oktatók a tangót egy az etnicitáshoz misztikus szálakkal kapcsolódó, földrajzilag meghatározott szellemi kulturális örökségként igyekeztek közvetíteni.

\subsubsection{A tangó, mint örökség: problémák a tangó szülooföldjének nézópontjából}

Az argentin antropológus, Hernán Morel (2017) a tangó szellemi örökséggé nyilvánítását és ennek következményeit tanulmányozta a Buenos Aires-i városi kultúrpolitika és a hagyományos tangó klubok közti interakciókon keresztül. Morel arról számol be, hogy 2005 és 2015 között a városi hatóságok váratlan és érthetetlen módon sorozatosan zárattak be hagyományos klubokat hosszabb- rövidebb időre. Néhány nagyon régi, emblematikusként is jellemezhetô milonga normális múködését is akadályozták ezek az intézkedések, amelyeket biztonsági feltételek és múködési engedélyek állítólagos hiányával indokoltak a hatóságok. Morel részletesen leír egy az intézkedések ellen tiltakozó performatív demonstrációt, amely során a városi kulturális hatóság épülete elé szervezett szabadtéri milongán a helyi tangós közösségek száznál is több tagja táncolt „,a patrimónium védelmében” (123.)

Morel elemzése több, a helyi tangós világ szempontjából az örökségesítés következtében felmerülő problémát artikulált. Ezek a problémák, kihívások fokozták a Buenos Aires-i tangós világ önszerveződését és közösségi reakciókat váltottak ki. A milongák kárára hozott adminisztratív lépések felhívták a figyelmet az intézkedések ésszerütlenségére, hiszen nyilvánvalóan nem vették figyelembe a milongák tényleges napi múködésének sajátosságait.

Morel kutatása ráirányította a figyelmet a tangó, mint szellemi kulturális örökség definíciójának hiányosságaira is. Észrevételei jelzik, hogy a rendszeres táncalkalmak, ezek fizikai terei, a hozzájuk kapcsolódó helyi közösségek, az általuk megvalósuló értékek, társas kapcsolatok és viselkedésformák alapvetô alkotóelemei a tangó kultúrájának. ${ }^{3}$

Összefüggésben állhat a milongák közösségei és a városi hatóságok közt kialakult konfliktus sorozattal és Morel ezekrôl írott elemzéseivel, hogy az UNESCO 2012-ben megrendelte hat hagyományos Buenos Aires-i milonga inventáriumának elkészítését. Az elkészült jelentés (Lacarrieu és Maronese, 2013) a hat milonga részletes leírását adta közre, amely hiányosságai ellenére is bemutatja a klubok szervezőit, a fizikai táncteret, a rendszeres látogatók csoportját, és az ott érvényes viselkedési szabályok egy részét.

${ }^{3}$ Fontos megjegyezni, hogy az örökségesítés következményeire és kritikájára irányuló elemzésében Morel teljességgel néma marad a nemzetközi tangóközösség hiányával kapcsolatban. 
Morel ugyancsak tanulmányozta a városi hatóságok által előmozdított nemzetközi tangóturizmus és a helyi tangós közösségek erre adott reakcióinak társadalmi dinamikáját. A Buenos Aires-i városvezetés kulturális hivatala a tangó örökségesítési folyamatának kezdete óta promotált tangós mega-rendezvényeket, tömeges tangófesztiválokat és tangó bemutatókat, nemzetközi tangóbajnokságokat, valamint milongának látszó tömeges táncrendezvényeket. Mindez vegyes érzéseket ébresztett a tangó helyi múvelőinek körében, akikkel nem egyeztettek ezekről az eseményekről. Mint Morel rámutatott, a szellemi kulturális örökség kontrollálására a turizmusipar részeként felülrôl hozott intézkedések konfliktusba kerültek ugyanezen örökség alulról szerveződő közösségi gyakorlataival.

\section{TANGÓ TURIZMUS ÉS A TANGÓ MARATONOK}

A nemzetközi tangó turizmus, vagyis a tangózás céljával külföldi országokba tett utazások nagyon fontos tényezői a tangó, mint globális jelenség alakulásának és több megközelítésből is mélyrehatóan tanulmányozták már (Davis, 2015; Stepputat, 2017; Törnquist 2013; Skinner, 2019).

Argentína évtizedek óta a tangó turizmus megkülönbözetett desztinációja kezdő és haladó szintû́ táncosok számára egyaránt. Amióta a tangó szellemi kulturális örökséggé vált, egy folyamatosan bővülő turistaipari ágazat szolgálja ki az egyénileg vagy csoportosan táncolni érkezőket. Kínálnak számukra szállást és étkezést, egyéni és csoportos táncórákat, tangó bemutatókat, elkísérik ôket a helyi tangó klubokba és cipőboltokba, sőt igény szerint külön egyéni táncpartnereket, más néven taxi táncosokat is kínálnak, akik segítenek a látogatóknak eligazodni a Buenos Aires-i milongák összetett világában. Az Argentina Tango weboldal jól illusztrálja a létező szolgáltatások körét, amelyek közt elérhetőek a különféle korosztályokhoz tartozó, egyénileg utazó nők számára kialakított speciális szolgáltatáscsomagok is. ${ }^{4}$ A városvezetés kulturális részlege által szervezett nagy nemzetközi fesztiválok és az éves tangó világbajnokság (Mundial de Tango) viszonylag új múfajok az argentin fôvárosban, bár az utóbbit már néhány évvel azelőtt elkezdték megrendezni, hogy a tangót 2009-ben szellemi kulturális örökséggé nyilvánították ${ }^{5}$. Az Észak- és Dél-Amerikában, Ázsiában és Európában folyó regionális elődöntőket a 2010-es évek eleje óta rendezik meg.

Nem célja e dolgozatnak a tangó turizmus gazdasági vetületeinek a tárgyalása, de azt hangsúlyozni kell, hogy mind a helyi táncélet, mind a külföldi tangós utak költségvonzatokkal járnak. Izgalmas lenne számba venni mindazokat a társas utazási formákat, amelyek tangós elemet is tartalmaznak, és megvizsgálni, ezek miként illeszkednek a résztvevők tangós tapasztalatainak sorába, de erre itt nem kerülhet sor. Több szerző tárgyalta a tangó argentínai és nemzetközi világához tartozók társadalmi és gazdasági jellemzőit (pl. Davis, 2015, Stepputat, 2019). Összefoglalóan és kicsit leegyszerúsítve megállapítható, hogy jellemzően jómódú, magasan képzett városi középosztálybeli egyének mélyülnek el az argentin tangó világában.

\footnotetext{
${ }^{4}$ ArgentinaTango weboldal. URL: https:/ / www.argentinatango.com/

${ }^{5}$ Lásd: https:/ / en.wikipedia.org/wiki/World_tango_dance_tournament
} 


\section{Kovács Nóra}

A mozgásforma Magyarországon az 1990-es évek közepén jelent meg először az International Dance and Movement Centre (IDMC) nyári kurzuskínálatában. Heti rendszerességgel több, mint két évtizede szerveznek tangó klubokat Budapesten. Ezek száma jelentősen megemelkedett az utóbbi években, 2019-ben már átlagosan nyolc milonga múködött hetente, és további három táncalkalom havonta. A tangó múvelésének anyagilag legkevésbé megterhelő módja, ha valaki a helyi tanárok csoportos óráin vesz részt, és a helyi klubokba jár le táncolni.

$\mathrm{Az}$ argentin gazdasági válság következtében az argentin állampolgárok nagy számban vándoroltak ki Európába. A 2001-es gazdasági összeomlást követően 800 ezren hagyták el az országot. ${ }^{6}$ A spanyol Nemzeti Statisztikai Intézet adatai szerint 2019-ben 268,292 argentin születésû személy élt Spanyolországban, abban az államban, amelynek népessége történelmileg is sok szálon kapcsolódik a Dél-Amerikai országhoz. A 2000-es évek elején és közepén a Buenos Aires-i társasági tangóélet több résztvevője döntött úgy, hogy Európában telepedik le, és a tangóból igyekszik megélni. Magyarországon 2019-ben két argentínai tánctanár kínált órákat a helybélieknek a több mint három tucat magyarországi tanár mellett, akik ugyancsak heti rendszerességgel tanítottak tangót. A viszonyítás végett érdemes megemlíteni, hogy bérletes rendszerben egy tangóóra ára megegyezett, vagy kicsit alulmúlta egy mozijegy vagy egy Pilates tornaóra árát: átlagosan 2000 forintba (6-7 Euróba) került.

A helyi milongák rendszeres látogatóinak ismétlődő tapasztalata, hogy külföldi tangó turisták is felbukkannak a táncparketten. A társasági tangósok általános szokása, hogy felkeresik egy adott város klubját, ha éppen arra járnak. Ez lehetôséget kínál, hogy új partnerekkel táncoljanak, és emellett személyes kapcsolatba lépjenek a helyi társadalom tagjaival. A rendszeres tangós táncalkalmak látogatása jellemzően olcsóbb, mint moziba menni; a milonga belépők 2019-ben jellemzően 1500 forintba kerültek.

A rendszeres helyi táncalkalmakon való részvételhez képest a többnapos nemzetközi fesztiválok, tangó maratonok, encuentro milonguero-k lényegesen költségesebb külföldi utazást, részvételi díjat, stb. jelentenek. A táncalkalmak e kategóriái magyarázatot igényelnek, mert speciális jellemzőik és a tangó világában elfoglalt szerepük jelentôségének növekedése megítélésem szerint kapcsolatban áll azzal, miként vélekednek a tangó világának autentikusságról a tapasztalt amatőr társasági tangótáncosok és miként igyekeznek megtalálni azt. Ez egy fontos pont, bár sporadikus empirikus adatok támasztják alá, ezért egyelőre inkább hipotézis.

Korábban az uralkodó nemzetközi rendezvényforma a tangó fesztivál volt. A 2000-es évek elején a fesztiválok határozták meg a magyarországi és az európai nemzetközi tangós piacot is. Újból Magyarország példáját idézve, az első jelentősebb tangó fesztiválok egyike a Kelet-Nyugat Tangó Fesztivál volt, amelyet 2004 szeptemberében tartottak a budapesti Millenáris Parkban. A fesztivált az argentin tangó magyarországi népszerúsítésre létrehozott kulturális alapítvány lelkes önkéntesei hozták tető alá7. Ahogy egyre több nemzetközi tangó maraton és encuentro milonguero került megszervezésre, a fesztiválok érzékelhetően elkezdtek teret veszíteni.

${ }^{6}$ iProfesional, 2009.

7 Erról további információk itt találhatók: https://fidelio.hu/klasszikus/tangofesztival-a-millenarison-131704.html 


\section{Kovács Nóra}

Amikor a maraton és az encuentro közti különbséggel kapcsolatos elképzeléseket firtattam, néhány tangós beszélgetőtársam jelezte, hogy nem érzékel ilyet. Más rendszeres maraton és encuentro-látogatók finom eltérést érzékeltek a két táncalkalmi forma között a résztvevők életkora és tánctudásszintje terén. Szerintük a maratonokra fiatalabb járnak, akik magasabb színvonalon tangóznak. Egy budapesti tanguera így fogalmazta meg a két forma különbségeit: „Szerintem a maratonokon magasabb a táncszínvonal, és nehezebb elérni, hogy a szervezők elfogadják a jelentkezésedet. Az encuentro-k kevésbé kompetitívek és általában a maratonok látogatóinál idősebbek vesznek rajtuk részt. És az encuentro-k talán kisebb rendezvények. De az is lehet, hogy nem" ${ }^{\prime 2}$. Jelen dolgozatban a két kifejezés egymás szinonimájaként szerepel.

A fesztiválok, a maratonok és az encuentro-k közt sok a hasonlóság. Általában mindhárom két-három napos rendezvényt jelöl, amely az argentin tangó köré szerveződik. Mindhárom során vannak táncalkalmak, azaz milongák, amelyekhez tangós DJ-k, vagy jóval ritkábban élő zenekarok biztosítják a zenét. Egyaránt célozzák a helyi és külföldi társasági tangó táncosokat. A szervezők gyakran igyekeznek különleges atmoszférájú helyszíneket megszerezni a rendezvényekre és a tér egy elkülönített sarkában rendszeresen lehet tangócipőt, esetleg ruhát is vásárolni.

De a fesztiválok fontos pontokon különböznek is a maratonoktól és az encuentro milonguero-któl. Előbbiek látványosabbak és remek belépési pontot kínálhatnak a tangóval éppen ismerkedőknek. A fesztiválok esti milongái szinte kötelezően kínálnak élő zenét és gyakran szakítják meg őket a tanárok és meghívott táncosok színpadi jellegú koreografált táncbemutatói. A fesztiválok jellemzően minden tudásszintnek kínálnak órákat, ez azonban a lehetséges résztvevők számára felveti a táncpartner hiányának problémáját. A fesztiválokra többnyire nem kötelező előre regisztrálni; részben ebből is fakadóan nem kiegyenlített a vezető és követő szerepekben táncolók aránya. A fesztiválok gyakran kerülnek megrendezésre nagyobb közönség befogadására alkalmas, bár jellemzően hangulatos helyszíneken.

Bár előfordulhatnak eltérések, a maratonok és encuentro-k ritkán fogadnak 250 főnél több résztvevőt, sőt akadnak, amelyek 150 főben húzzák meg a felső határt. A szervezők kiegyenlített vezető-követő arányt ígérnek, megszabják a helyi és a nemzetközi résztvevők arányát, és többnyire öt délutáni-esti, illetve éjszakai-hajnali blokkba rendezett 24-30 órányi tánclehetôséget ígérnek a résztvevőknek. A szervezők általában hangsúlyozzák, ső́t elvárják a közeli tánctartást a táncparketten, valamint a Buenos Aires-i milongákban kialakult szavak nélküli gesztusokból álló kódrendszer, a cabeceo ${ }^{9}$ használatát a potenciális táncpartnerek egyezkedéséhez (erről lásd Kovács, 2006).

\footnotetext{
${ }^{8}$ Olgi, 40 éves társasági tangótáncos.

${ }^{9}$ Fejbiccentés (spanyol).
} 
Kovács Nóra

\begin{tabular}{|c|c|c|c|}
\hline $\begin{array}{c}\text { A nemzetközi maraton vagy } \\
\text { encuentro neve }\end{array}$ & Kezdő év & $\begin{array}{c}\text { Évente } \\
\text { hányszor }\end{array}$ & URL \\
\hline Noches de Hungría & 2011- & 1 & https://noches.hu/ \\
\hline $\begin{array}{l}\text { Royal Budapest Tango Mara- } \\
\text { thon/ Primavera en Budapest } \\
\text { Tango Marathon/ Amor en } \\
\text { Budapest Tango Marathon }\end{array}$ & 2012- & 3 & $\begin{array}{c}\text { https: / / royalbudapest.org/ } \\
\text { http:/ / primaverabudapest.org/ } \\
\text { https: / / amorenbudapest.org/ }\end{array}$ \\
\hline $\begin{array}{l}\text { Danube Tango Marathon/ } \\
\text { Summer in the City/Winter in } \\
\text { the City }\end{array}$ & 2015- & $1-2$ & $\begin{array}{l}\text { www.danubetango.hu } \\
\text { https://gab454.wixsite.com/dan- } \\
\text { ubetangomarathons/history }\end{array}$ \\
\hline Secreto & 2016- & 1 & https:// secreto.hu/ \\
\hline $\begin{array}{l}\text { Budapest Modern Tango Mar- } \\
\text { athon }\end{array}$ & 2019- & 1 & $\begin{array}{c}\text { https: / / neotango.org/event/ } \\
\text { budapest-modern-tango-mara- } \\
\text { thon-1-2019-11-08-2019-11-11-60/ } \\
\text { register }\end{array}$ \\
\hline $\begin{array}{l}\text { Mascarada Encuentro } \\
\text { Milonguero }\end{array}$ & $2020-$ & 1 & $\begin{array}{l}\text { https:/ / mascarada-milonguero. } \\
\text { blogspot.com/p/blog-page.html }\end{array}$ \\
\hline
\end{tabular}

1. táblázat: Tangó maratonok Magyarországon (2020. március).

Az 1. táblázat azt mutatja, miként nyertek teret a maratonok Magyarországon 2011 óta. A 2020 márciusát megelőző 12 hónapban kilenc ilyen nemzetközi esemény valósult meg. A tangó világában számos ellentmondásos társadalmi gyakorlat él. Ezek közt kiemelt figyelmet kapott a nemek közti egyenlőtlen hatalmi viszony, amelyet több szerző kritikai megközelítésben elemzett. A maratonok jellegzetességeinek áttekintése egy másik ellentmondásos kérdést hoz elótérbe. A fesztiválokkal ellentétben a maratonok és encuentro-k szelektív, elitista események. A részvétel formális online jelentkezéshez kötött, amelyet a szervezők csak részben nyilvános és szubjektív szempontok szerint mérlegelnek. A népszerú maratonokra nehéz bekerülni, sok jelentkezőt elutasítanak a szervezők. Tangós beszélgetőtársaim közül többen hangsúlyozták, hogy a követő táncosok (túlnyomó többségükben nők) sokkal alacsonyabb eséllyel kapnak pozitív választ a szervezőktól, mint a vezetők (jellemzően férfiak). Egyes nemzetközi maratonok, köztük a legmagasabb presztízzsel rendelkezók zártkörúek, meghívásos alapon múködnek.

A tapasztalt társasági tangótáncosok nézőpontjából a maratonok létezése logikus és természetes. Érdekes azonban, hogy ezeknek a háromnapos hétvégi táncalkalmaknak az eredete minden jel szerint nem a La Plata vidékén keresendő. Barátai, tanítványai és táncos társai egybehangzó véleménye szerint Eric Jorissen találta ki a tangós 


\section{Kovács Nóra}

találkozók azon típusát, amelyet a tangó maratonok „,anyjának” tekinthetünk ${ }^{10}$. Jorissen az 1980-as években kapcsolódott be a Buenos Aires-i tangó világába, amikor azt alapvetően a régi idők idősebb képviselői határozták meg. Tanítványa, majd közeli barátja lett a tangó nagy tiszteletben álló táncos képviselőjének, Pepito Avellanedának. Hollandiába visszatérve létrehozta az El Corte tangóiskolát és táncteret Nijmegenben. A Jorissen a messzirôl érkező táncosoknak az El Corte épületében biztosított szállást; az általa létrehozott iskola és klub felvállalt értékei közé tartozott a barátság és a közösség építése. Állításuk szerint Jorissen és az El Corte szervezték az első tangó maraton-jellegú rendezvényt 1993-ban.

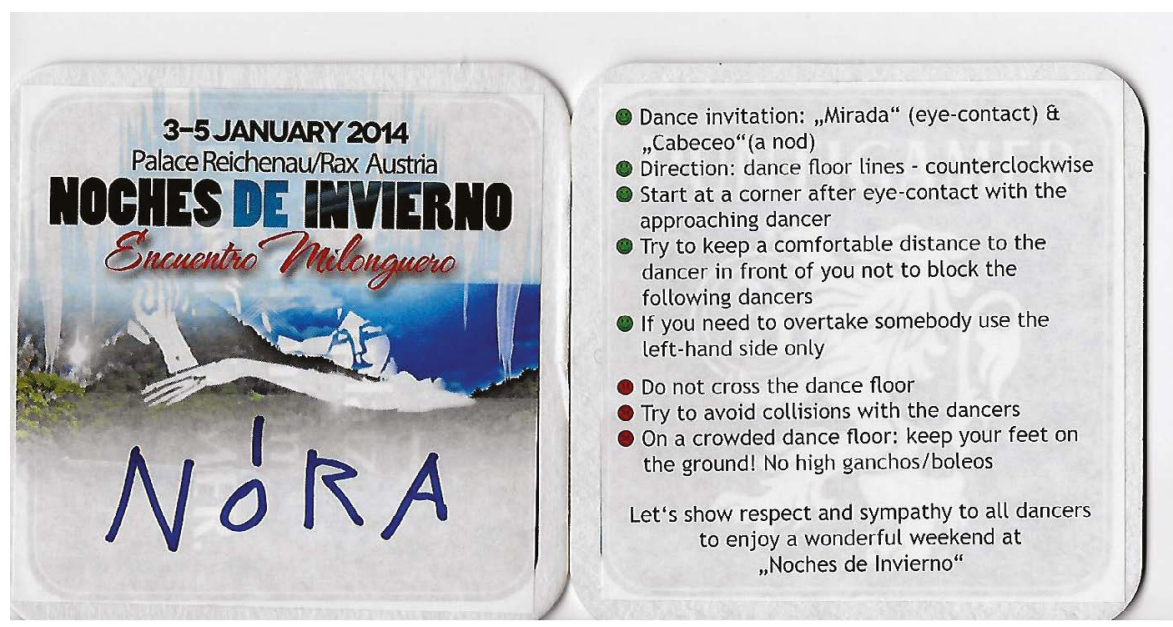

1. ábra: A Noches de Invierno Encuentro Milonguero során a résztvevőknek kiosztott poháralátét előlapja és hátoldala (Rax, Ausztria 2014).

A Noches de Invierno (jelentése Téli Éjszakák, sp.) Encuentro Milonguero kezdetén a szervezők által a résztvevőknek kiosztott poháralátét (1. ábra) kettős célt szolgált. Egyfelől a környezet fenntarthatóságát szolgálta, mert névvel azonosítható helyet kínált a múanyag poharaknak. Ezzel egyidejûleg emlékezetette a tangósok nemzetközi csoportját fontosnak tartott, a milongán érvényes közösségi irányelvekre. Ezek szabályozni kívánták a felkérés módját, az óra járásával ellenkező haladási irányt és a követési távolságot a táncparketten, valamint emlékeztettek arra, hogy a látványos és helyigényes egyéni táncdíszítések veszélyeztethetik a közelben táncolókat.

Régóta táncoló, tapasztalt és elkötelezett magyar és szlovén társasági tangósok többen megfogalmazták növekvő igényüket a részvételi, közösségi tangóélményekre, amelyeket egyben autentikusabb tánctapasztalatként is éltek meg. A bevezetôben említett lelkes maraton-beszámoló egy Trieste, tango y Tú (Trieszt, tangó és Te) elnevezésû, egy népes helyi tangós baráti közösség által évente megrendezett tangós hétvégére utalt, akiknek kifejezett szándéka volt, hogy informális közösséget és

${ }^{10} \mathrm{http} / /$ / www.elcorte.com/ what-else/ history-of-el-corte 


\section{Kovács Nóra}

nemzetközi tangós élményt hozzanak létre. Az informalitás ilyen magas fokával és a helyi tangós baráti közösség nagymértékú személyes támogatásával ez a rendezvény kiemelkedett a tipikus tangó maratonok közül. Ezzel együtt az Eric Jorissen és barátai által létrehozott El Corte közösségi projekt, vagy a Tango Nieve találkozó Szlovéniában, és hasonló események számos a nemzetközi tangó világában aktív táncos számára az tangó univerzális autentikusságának megvalósulását képviselik.

\section{7. ÖSSZEFOGLALÁS}

Ez a tanulmány a 2009-ben szellemi kulturális örökséggé nyilvánított Tangó örökségesítésére adott tudományos és közösségi reakciókra fókuszált. Két a tangó nemzetközi világában párhuzamosan létező jelenségcsoportot tárgyalt. Egyfelől áttekintette az argentínai és nemzetközi tangó-szakirodalom, valamint az argentínai tangóközösségek által megfogalmazott kritikákat az örökségesítéssel kapcsolatban. Másfelől e kritikai észrevételek összefüggésében mutatta be és tárgyalta a globális tangó világában megjelent, 2009 óta jelentősen növekvő népszerúségú táncalkalmi formát, a tangó maratont, vagy encuentro milonguero-t. A tangó globális világát sok különböző identitású, különféle érdektől, céltól, esztétikai elvtől vezérelt szereplő alakította és formálja ma is. Mindazonáltal úgy túnik, hogy a tanulmányban tárgyalt újfajta nemzetközi táncalkalmak a velük kapcsolatos ellentmondások, és szelektivitás ellenére sok elkötelezett, tapasztalt társasági tangótáncos számára az általuk képviselt milonga-értékek és közösségi magatartási szabályok érvényre juttatása miatt is komoly vonzerővel rendelkeznek.

Kutatók felhívták a figyelmet a tangó, mint szellemi kulturális örökség meghatározásának torzításaira és hiányosságaira és több ezzel kapcsolatos konkrét problémát azonosítottak. Rámutattak a tangó idealizált definíciójára és az örökségesítés mögötti politikai és gazdasági szándékokra. A tangó definíciója nem utalt arra, hogy a tánc egy jelentésekkel teli közösségi gyakorlat, amelyet társas kapcsolatok és viselkedési szabályok szőnek át. A meghatározáson kívül rekedt a tangót táncoló népesség többsége, akik a La Plata vidékén kívül éltetik és fejlesztik tovább ezt a hagyományrendszert. Összefoglalásként elmondható, hogy az örökség csupán szûken vett kulturális és nem társadalmi jelenségként definiálta a tangót.

A múfaj sok kutató érdeklődését ébresztette fel, azonban az így keletkezett tudás és a tangóról, mint társadalmi és közösségi gyakorlatról szóló kutatási eredmények csekély és szelektív hányada került bele abba dokumentumba, amely alapján az örökségesítési döntés megszületett. A tangó alapvetően mint zene, vers, színpadi előadó mûvészet és a La Plata vidéki történelem egy darabja jelent meg a felterjesztők értelmezésében, amely figyelmen kívül hagyta a tangó mindennapi fizikai gyakorlatát és közösségi tevékenység-jellegét. Fontos hangsúlyozni, hogy a rendkívül kifinomult és részleteiben is kidolgozott, improvizáción alapuló, játékos és folyamatosan fejlődő, alakuló tánchagyomány volt az a tangó jelenségkörén belül, ami oly sokakat megragadott szerte a világon, és ami globális jelenséggé tette. A tangó nemzetközi vonzereje a közösségi mozgásgyakorlat nélkül minden bizonnyal sokkal korlátozottabb lenne.

Miután 2009-ben szellemi kulturális örökséggé nyilvánították, Buenos Aires kulturális kormányzata saját ellenőrzése alá vonta a megnövekedett tangó célú 
turizmust. Figyelmen kívül hagyta azonban a lokalitásokhoz köthetô, jelentéssel és társas kapcsolatokkal teli hagyományos Buenos Aires-i milonga-közösségeket, ami összetûzésekhez vezetett a városi hatóságok és a városi táncos közösség szervezői és résztvevői között. Talán ezeknek is köszönhetô volt az UNESCO szándéka, hogy több információt gyűjtsön az argentin fôváros hagyományos milongáiról, ami hosszabb távon talán a tangó pontosabb és inkluzívabb meghatározásához vezethet - legalábbis a La Plata vidékének vonatkozásában.

A hatalmas argentínai tangó fesztiválok, bajnokságok és turistákat célzó mega-rendezvények megjelenésével párhuzamosan a tangó nemzetközi világában elérkezett a maratonok és az encuentro milonguero-k időszaka is. A fesztiválokkal, luxus tangó társasutazásokkal, a tangó Mekkájába, Buenos Airesbe tett zarándoklatokkal együtt a maratonok és encuentro-k is részét képezik a tangó turizmus növekvő volumenú gazdaságának. Mindezek különféle manifesztációi ennek az ellentmondásokkal teli, emberi találkozásokban és dinamikus harmóniákban gazdag, sokrétû, globális városi táncos rétegkultúrának. Ebben az összetett világban a maratonok és a milonguero-stílusú tangótalálkozók a bensőségességen és a közös táncokon keresztül sokak számára esszenciális, autentikus táncélményt jelenítettek meg.

\section{Hivatkozások}

Archetti, E. P. (2003). Masculinidades. Fútbol, tango y polo en la Argentina. Editorial Antropofagia.

Azzi, M. S. (1991). Antropologia del tango. Los protagonistas. Ediciones de Olavarria.

Davis, K. (2015). Dancing Tango. Passionate Encounters in a Globalizing World. New York University Press. https: / / doi.org/10.18574/nyu/9780814760291.001.0001

Dinzel, G., \& Dinzel, R. (1997). El tango. Una danza. Sistema dinzel de notacion coreografica. Ediciones Corregidor.

Ferrer, H. A., \& del Priore, O. (2000). Inventario del Tango. Fondo Nacional de Las Artes.

Gobello, J. (Ed.). (1997). Letras de tangos. Selección (1897-1981). Ediciones Nuevo Siglo.

iProfesional (2009, August 12). Desde la crisis del 2001, 800.000 argentinos se fueron del país. https://www.iprofesional.com/management/85843-Desde-la-crisisdel-2001-800000-argentinos-se-fueron-del-pais

Kovács, N. (2006). Szavak nélkül - a milonga kommunikációs rendszere. In A. Gergely, R. Papp, \& Cs.Prónai (Eds.), Kultúrák között. Hommage à Boglár Lajos (pp. 433-439). Nyitott Könyvmúhely Kiadó.

Kovács, N. (2015). Komoly könyv az argentin tangóról. TABULA, 16(1-2).

Labraña, L., \& Sebastián, A. (2000). Tango. Una historia. Corregidor.

Lacarrieu, M., \& Maronese, L. (2013). Inventario de seis milongas de Buenos Aires. Experiencia piloto de participacion comunitaria. UNESCO - Oficina Regional de Ciencia para America Latina y el Caribe, Sector Cultura, Representación de la UNESCO ante el MERCOSUR. 


\section{Kovács Nóra}

Lötzke, D., Ostermann, T., \& Büssing, A. (2015). Argentine tango in Parkinson disease - a systematic review and meta-analysis. BMC Neurology, 15(226). https://doi.org/10.1186/s12883-015-0484-0

Morel, H. (2009). El giro patrimonial del tango: políticas oficiales, turismo y campeonatos de baile en la ciudad de Buenos Aires. Cuadernos de Antropología Social $\mathrm{N}^{\mathrm{o}} 30$ (pp. 155-172).

Morel, H. (2012). Vuelve el tango: “Tango argentino" y las narrativas sobre el resurgimiento del baile en Buenos Aires. Revista del Museo de Antropología 5 (pp. 77-88).

Morel, H. (2013) Buenos Aires, la Mecca del tango: procesos de activacion, megaeventos culturalesm turismo y dilemas en el patrimonio local. PUBLICAR. En Antropología y Ciencias Sociales No 15 (2013) Año XI, N XV, Diciembre 2013. https:// doi.org/10.5007/2175-8034.2013v15n1-2p251

Morel, H. (2017) "Se armó la milonga": acerca de las políticas, el patrimonio y los espacios de baile de tango en la ciudad de Buenos Aires, Argentina. Antipoda. Revista de Antropologia e Arqueologia. No. 27. Bogotá, enero-abril 2017. pp. 121140. DOI: https:// doi.org/10.7440/antipoda27.2017.05

Pinniger, R., Brown, R., Thorsteinsson, E., \& McKinley, P. (2012). Argentine tango dance compared to mindfulness meditation and a waiting-list control: a randomized trial for treating depression. Complementary Therapies in Medicine, 20(6), 377-384. https:// doi.org/10.1016/j.ctim.2012.07.003

Savigliano, M. E. (1995). Tango and the political economy of passion. Westview Press, Boulder.

Sierra, L. A. (1985). Historia de la Orquesta Tipica. Evolucion instrumental del tango. Corregidor.

Skinner, J. (2014). Argentine Tango: social dance health 'to' you. Anthropology $\mathcal{E}$ Aging Quarterly, 34(4) (April 2014), 260-263. https://doi.org/10.5195/aa.2014.5

Skinner, J. (2019). 'It's tango!' Communicating intangible cultural heritage for the dance tourist. In: C. Palmer, \& J. Tivers (Eds.), Creating heritage for tourism. Routledge, Oxon.

Stepputat, K. (2015). Tango, the not quite intangible cultural heritage. In E. Ivancich Dunin (Ed.), 28th Symposium of the ITCM Study Group on Ethnochoreology 7-17 July 2014 Korcula, Croatia (pp. 336-341). ICTM Study Group on Ethnochoreology - Institute of Ethnology and Folklore Research Croatia.

Stepputat, K. (2017). Tango journeys - going on a pilgrimage to Buenos Aires. In K. Stepputat (Ed.), DANCE, SENSES, URBAN CONTEXTS. Dance and the Senses. Dancing and Dance Cultures in Urban Contexts (pp. 195-205). ICTM Study Group on Ethnochoreology - Institute of Ethnomusicology, University of Music and Performing Arts Graz.

Stepputat, K. (2019). Tango in Paradise. Why dance tango argentino on Bali? In P. Matusky \& W. Quintero (Eds.), Proceedings of the 5th Syposium: The ICTM Study Group On Performing Arts Of Southeast Asia (pp. 201- 204). Department of Sabah Museum, Ministry of Tourism, Culture and Environment Malaysia.

Taylor, J. (1998). Paper tangos. Duke University Press. https://doi.org/10.2307/j. ctv11smw5p 


\section{Kovács Nóra}

Törnquist, M. (2013). Tourism and the globalization of emotions. Routledge Advances in Feminist Studies and Intersectionality. Routledge.

UNESCO (2009a). Tango. Argentina y Uruguay. https://ich.unesco.org/en/RL/ tango-00258

UNESCO (2009b). CONVENTION FOR THE SAFEGUARDING OF THE INTANGIBLE CULTURAL HERITAGE. Nomination for inscription on the Representative List in 2009 (Reference No. 00258). Tango. https: / / ich.unesco.org/ doc/src/26041EN.doc

UNESCO (2009c). Decision of the Intergovernmental Committee: 4.COM 13.01. https: / / ich.unesco.org/en/decisions / 4.COM/13.01

Viladrich, A. (2013). More than two to tango. Argentine tango immigrants in New York City. The University of Arizona Press. 